examples of flint implements from the caves, is a remarkable example of delicate workmanship in the form of a leaf-shaped Solutrean point, measuring about nine inches long.

\section{Excavations on Pre-Roman Sites in Britain}

DURING the past five years, land development at Ewell in Surrey has brought to light extensive evidence not only of Roman occupation, but also of a succession of pre-Roman settlements of considerable importance, some indeed dating so far back as the Mesolithic Age. A further find recently reported (The Times, April 14) lies west of the Epsom road, some two hundred yards west of the recently proved line of the Roman Stane Street. The discovery is due to Mr. A. W. G. Lowther. It includes relics of the Mesolithic Age, the Early Iron Age, dating at about 500 B.C. and of the Claudian and Hadrianic periods. The site is near that at Thayles Hill, on which Roman and Saxon remains were found a few years ago. The attraction to settlers here, it has been pointed out, was the dry belt of Thanet sand, which runs through Ewell, and the plentiful supply of water available from the famous springs. Mr. Lowther has dug out at about two feet depth a Roman road, in part well preserved, of the standard width of twenty-one feet. It is constructed of chalk blocks overlying the sand, and a surface layer of flints, in which was Hadrianic and later pottery. A much-worn coin of Domitian was found in an underlying well. Below the road were first century Roman pottery and a domestic oven, two pre-Roman ditches, pre-Roman iron slag and part of an iron ingot and much pottery dating back to 500 B.c., as well as a big light brown pottery watercontainer of the late Early Iron Age. Some twenty yards to the west of the road were the remains of a Romano-British hut, with Roman debris. A detailed account of the find is to be communicated to the Society of Antiquaries of London by Mr. Lowther in due course.

A sITe from which it may be anticipated that preRoman material of no little interest will be obtained is that at Silchester, on which stands, or rather stood, the Roman city of Calleva Atrebatum. Systematic excavations are to be carried out there under the direction of the Office of Works and the Archæological Institute. The Roman city was under excavation for a number of seasons around the beginning of this century by a Committee of the Society of Antiquaries of London under the direction of $\mathrm{Mr}$. (afterwards Sir) W. H. St. John Hope, the assistant secretary of the Society. Much important material was then obtained from the site, which is now in the Reading Museum, and valuable detailed reports of the results of the excavation were issued. Attention was directed, however, exclusively to the remains of Roman date; but it is obvious that a position of geographical importance to attract the Romans must have invited prior settlement. In fact, it is believed that this is the site of a large early British settlement known as Caer Segont, and that this was surrounded by the mound and ditch, similar to that at Avebury, which encloses a much larger area than the Roman walls, presumably erected at a later date. Trial excavations in the area between the mound and the walls were carried out last year by Dr. Mollie Cotton and a party of volunteers; but operations are to be resumed on a more extensive scale this year, the excavators being drawn from Reading and other universities.

\section{The Science Museum: New Optical Instruments}

THE Science Museum has recently received from Mr. Thomas H. Court a gift of a large number of early optical, mathematical and astronomical instruments, some of which are now displayed in a single group in the Optics Gallery. Mr. Court, who celebrated his seventieth birthday last year, has spent most of his life collecting early scientific instruments, and he is a foremost authority on the subject. For the last thirty years he has been presenting his best acquisitions to the nation, so that his gifts to the Science Museum now total more than nine hundred. The seventy objects which comprise Mr. Court's most recent benefaction include an Italian recipiangle of about 1600 . This is an instrument used for measuring angles in surveying, and it is also marked with lines and scales which can be used for making calculations. There is an optometer invented by Thomas Young for testing eyesight and prescribing spectacles, there are early telescopes with vellum tubes, silver drawing instruments, a diagonal glass by means of which the visitor to the theatre or opera could observe his fellow spectators while appearing to be looking through his glass at the stage, and there are several fine astronomical reflecting telescopes by such noted eighteenth century opticians as James Short, John Bird and C. S. Passemant. Among the microscopes presented are several rare instruments of the seventeenth, eighteenth and early nineteenth centuries, notably a beautiful compound microscope of the Divini-Campani form with silver mounts, a number of very fine Culpeper-type microscopes and some of the earliest achromatic microseopes by English and Continental makers.

\section{Gas Fuel for the Internal Combustion Engine}

Tнш internal combustion engine began with gas as fuel, but the use of concentrated liquid fuel has determined its vast development in all fields of transport. Circumstances, too familiar to mention, have in recent years caused a renewed attention to the possibilities of reverting, in part at least, to the use of gaseous fuel from coal and even coal itself. In Continental countries this has been encouraged by fiscal and other forms of State aid. On March 27-28, the Institution of Mechanical Engineers held a conference at Swansea, when the position of the subject was reviewed. It was reported that in 1938 a producerfed passenger bus had maintained for one year a regular service from Inverness covering 32,000 miles. Its fuel cost was $£ 90$-as against $£ 253$ for petrol and $£ 136$ for oil. There was a charge for cleaning and attention of $£ 30$. In all producer-fed vehicles one must reckon on a 30 per cent loss of power owing 
to extra weight and cost due to the producer. On the Continent there are many gas-engined small vessels fed by producer gas. The position attained by engines fed by compressed gas was reviewed and it was considered that engines using injected fuel with high compression ratios will give performances equal to those of compression ignition engines operated with fuel oil. Progress with road vehicles has been determined by the use of thin walled containers of alloy steel capable of working at $3,500 \mathrm{lb}$. pressure. Dr. H. Wahl gave an optimistic account of the position and future of an engine running on coal dust.

\section{National Smoke Abatement Society}

For many years the National Smoke Abaternent Society, from headquarters in Manchester, pursued its modest efforts to secure a purer air and for the last ten years it has issued a quarterly journal. Since its removal to London, its efforts have been accompanied by greater progress. Even Whitehall has almost gone over to smokeless fuel and the L.C.C. has become more active. The extensive rebuilding in progress all over Great Britain is providing an unusual opportunity to diminish atmospheric pollution. Even the coal industry, long indifferent to the manner in which its wares were consumed, is showing an increased desire to avoid the reproach of causing smoke. The Society has taken a further step by issuing its journal in a new form, larger, more ambitious and under the more attractive name of Smokeless Air. This will be issued quarterly at $1 s$. and for $2 s .6 d$. post free per annum. The first number of the new series is bright and well produced, containing news of the movement and interesting articles on the subject of atmospheric pollution. At its price it ought to receive a much wider circulation.

\section{Telephone and Telegraph Statistics of the World}

IN Electrical Communications of October 1938, statistics of the telephone and telegraph services of the world are given. The telephone development of the world by countries is first discussed, the figures taken being for January 1937. North America possesses nearly 54 per cent of the total number of telephones in the world, the United States alone possessing nearly 50 per cent, and having $14 \cdot 4$ per cent per 100 of the population. South America possesses 2 per cent of the total and nearly 1 per cent per 100 of the population. The whole of Europe possesses 36.5 per cent of the total world number and has an average of 2.4 per 100 of the population. Great Britain and Northern Ireland, France, Germany, Italy and Russia have $7 \cdot 5,4 \cdot 0,9 \cdot 25,1 \cdot 5$ and $2 \cdot 6$ per cent of the total world telephones and $5 \cdot 9,3 \cdot 5,5 \cdot 1$, 1.3 and 0.6 per 100 of the population. Asia possesses nearly 4.6 per cent of the world's total, of which about three quarters belong to Japan. Africa possesses about 0.9 per cent of the world's total, of which more than half belong to the Union of South Africa. Oceania possesses nearly $2 \cdot 3$ per cent, Australia having 1.5 per cent. The number of telephones per 100 of the population is also given for large cities. Washington and San Francisco head the list each with 37. Stockholm comes next with 35. Then New York with 22, London with 16, Paris with 15, Berlin with 13, Rome with 8 , Tokyo with $3 \cdot 9$, Moscow with $3 \cdot 5$ and Shanghai with $3 \cdot 4$. In Canada, Montreal with more than a million inhabitants has 16 telephones per 100 of the population, and Toronto with more than three quarters of a million inhabitants has more than 25 telephones per hundred. In 1936, the total number of 'wire' communications, that is, of telephone conversations and telegrams per capita in Canada was 222, of which only 1 was a telegram. In the United States it was 211,1 being a telegram, and in Great Britain and Northem. Ireland it was 44, the number of telegrams sent per capita being a little greater than 1 .

\section{Meteorology in India}

THE report on the Administration of the Meteorological Department of the Government of India in 1937-38 shows that certain undertakings that had been under consideration for a number of years were carried out. Of these the most important is considered to be the daily preparation of an afternoon synoptic weather chart at the Meteorological Office at Poona, which was begun on April 1, 1937. This has enabled that office to issue forecasts twice a day instead of only once. This afternoon synoptic chart is printed in the Indian Daily Weather Report, and adds greatly to the value of that report. Another important development was introduced on August 1, 1937, when the short-wave aeronautical wireless stations at Karachi and Calcutta began to issue regional broadcasts of synoptic data twice daily. The new Burma Meteorological Department followed this lead by beginning the broadcasting of data for stations in Burma from October 1, 1937. With the commencement by the Posts and Telegraphs Department of the construction of a short-wave wireless station at Poona, the time is approaching for the issue from headquarters of collective and regional synoptic issues. Further plans were made in accordance with recommendations made at a meteorological conference held in Delhi in December 1936. They included the reopening of a forecasting office at Delhi and the transfer of the Upper Air Office from Agra to Delhi. These plans were approved in principle by the Government of India, but sanction for putting them into effect had to be postponed owing to the unfavourable financial situation. Another new development was the introduction at the request of the Royal Indian Navy of an arrangement for broadcasting synoptic data and weather bulletins for the whole of the Indian waters from the Navy Wireless Station at Bombay, for the benefit of shipping. The new broadcasts are additional to those issued from the civil wireless stations at Bombay and Calcutta.

\section{Osiris}

Vor. 4, part 2 of Osiris, edited by Dr. G. Sarton, published in 1938, is a monograph on "Science, Technology and Society in Seventeenth Century England", by Robert K. Merton, and its content is 